\title{
A10 アーチェリー矢の空力特性 -JAXA's 60cm MSBS 実験- Aerodynamic Properties of an Archery Arrow - JAXA's 60cm MSBS Experiments -
}

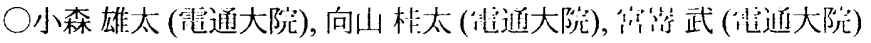

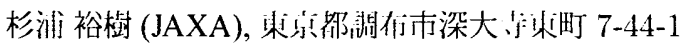 \\ Yuta KOMORI, Keita MUKAIYAMA, Takeshi MIYAZAKI (UEC) \\ 1-5-1 Chofugaoka Chofu, Tokyo, Japan \\ Hiroki SUGIURA (JAXA) \\ 7-44-1,Higashimachi,Jindaiji,Chofu,Tokyo,Japan
}

東宗都阅彻市调们ヶ丘 1-5-1, E-mail: Komori@miyazaki.mce.uec.ac.jp, miyazaki@mce.uec.ac.jp

\begin{abstract}
We performed wind-tunnel experiments with two Archery arrows $(\mathrm{X} 10, \mathrm{~A} / \mathrm{C} / \mathrm{E})$ without mechanical support on JAXA's Magnetic Suspension \& Balance System. We measured the relation between Reynolds number and drag coefficient, as well as we checked the relation between drag coefficient, lift coefficient and pitching-moment coefficient with the angle of attack. We found that the vanes impose a lift force and increase the orientational stability. In the available range of Reynolds $\left(0.3 \times 10^{4}<R e<2.5 \times 10^{4}\right)$, the boundary layer on the arrow shaft remained laminar. We compared these results with experiments of arrows in free flight which we recorded with two high-speed video cameras. We also compared the results of X10's aerodynamic propertie with $\mathrm{A} / \mathrm{C} / \mathrm{E}$ 's.
\end{abstract}

\section{1. 緒言}

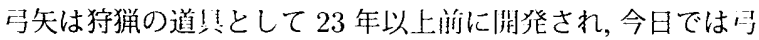
道・オリンピック競技のアーチェリーといったスポーッ刖具と

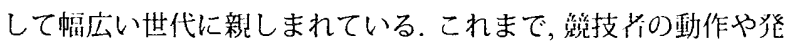
射装置に関する研究は行われて来たが, 矢の空力特性についての 研究は少なく, Sawada ${ }^{(1)}$ による矢羽0ない矢 (鏃なしと円錐鎕) に関する風洞実験, 和弓の矢の空力特性, クロスボウ矢の先端形 状と空力特性の関係の解明 (2) とに見られる程度である. 飛翔中 の矢は矢羽の影響により矢軸周りに回転するばかりでなく,たわ み振動するため,とても複雑な運動をしていることがその理由で ある.たわみ振動に目をつぶり, 矢が剛体運動をすると仮定して も, 矢のように非常に細長い物体の空力特性を風洞実験で測定す る際には, 固定支持具の存在が測定精度を大きく劣化させること が䱈念される. また, 飛翔中の矢は重心の進行に対して矢軸が傾 いて飛翔している可能性がある.この埸合には缃回方向に波数 1

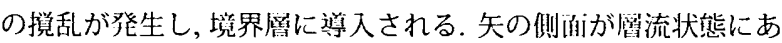
るか乱流状態にあるかは, 流体力学的な維点からも眮味深い㖿題 である.

本研究では,アーチェリー矢を舁験対像とし, JAXA の磁力支 持天秤装置 (以降 MSBS と呼ぶ.) を胕いて, 固这支持都の)ない風 洞実験を行う。アスペクト比の異なるアーチェリー矢のシャフ トを 2 種類 $(\mathrm{X} 10, \mathrm{~A} / \mathrm{C} / \mathrm{E})$ ，鏃を 2 種類（椎型流線形）を用い て空力特性に及ぼす影響を調べる.「X10」の矢に関しては害際 の射手が放つ矢の速度領域で测定を行うために, 模型矢で実験を 行う.

\section{2. 無次元量の定義}

本研究では以下の無次元量を使用して解析を行う.

\section{1 マッハ数: $M$}

流体の圧縮性の尺度となる無次元量であり，次式で定義される．

$$
M=\frac{U}{a}
$$

ただし $U$ は流速 $[\mathrm{m} / \mathrm{s}], a$ は等速 $[\mathrm{m} / \mathrm{s}]$ である.

一般に $M<0.30$ 流れでは, 非玨綰性流体として取り扱うこと が出来る. 矢の速度は $60[\mathrm{~m} / \mathrm{s}]$ 程度であり, マッハ数が 0.2 程度

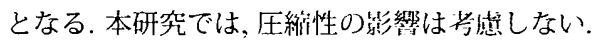

\section{2 レイノルズ数: $R e$ 数}

物体回りの流速をレイノルズ数を用いて, 無次元化する.レイ ノルズ数は以下の式で定義する.

$$
R e=\frac{V d}{\nu}
$$

ここで, $V$ は矢の速度 $[\mathrm{m} / \mathrm{s}], d$ は矢の平均直径 $[\mathrm{m}], \nu$ は空気の 動粘性係数 $\left[\mathrm{m}^{2} / \mathrm{s}\right]$ である.

2.3 抗力係数: $C_{D}$

抗力係数 $C_{D}$ は以下の式で定義する.

$$
F_{\text {drag }}=\frac{1}{2} \rho V^{2} S C_{D}
$$

ここで, $F_{\text {drag }}$ は抗力 [N], $\rho$ は究気の密低 $\left[\mathrm{kg} / \mathrm{m}^{3}\right], S$ は矢の断任 箖 $\left[\mathrm{m}^{2}\right]$ である. また, 飛翔央験においては速度诚衣率 $D[1 / \mathrm{m}]$ か ら, 以下の式で $C_{D}$ を求めた.

$$
C_{D}=\frac{m D}{\rho S}
$$

$m$ は矢の所量 $[\mathrm{kg}]$ である.

2.4 揚力係数: $C_{L}$

掦力係数 $C_{L}$ は以下の式で这䉝する.

$$
F_{\text {lift }}=\frac{1}{2} \rho V^{2} S C_{L}
$$

ここで, $F_{\text {lift }}$ は揚力 $[\mathrm{N}]$ である.

2.5 縦摇れ(ピッチング) モーメント係数: $C_{n}$. 縦摇れモーメント係数 $C_{m}$ は以下の式で追笺する.

$$
M=\frac{1}{2} \rho V^{2} S L C_{m}
$$

ここで, $M$ は縦摆れモーメント $[\mathrm{N} \cdot \mathrm{m}], L$ は矢の全長 $[\mathrm{m}]$ である.

\section{3. 実験装置及び模型}

3.1 MSBS 風洞

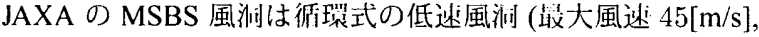
風速 $30[\mathrm{~m} / \mathrm{s}]$ での変動率 $0.06 \%$ ) である.Fig1 の様に 0 9 のコ 
イルを配置し, 各コイルから生じる滋気力を制御することで, 模 型の支持を行う。通痋時に测定物体を支持するために必要な電流 值を測定することで,物体に働く空気力を求めることができる.

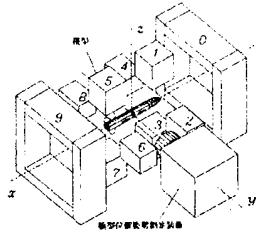

Fig. 1 コイル阢注!

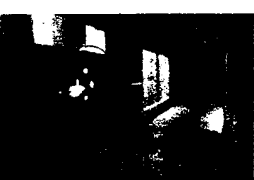

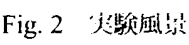

\section{2 矢}

アーチェリー競技で使用されている矢, $「 \mathrm{X} 10 」, 「 \mathrm{~A} / \mathrm{C} / \mathrm{E} 」(\mathrm{Fig} 3)$ を用いた実験を行った。この 2 種類の実際の矢の直径は中心付近 が最も太い樽型 (バレル) 形状になっている. しかし, 今回風洞実 騃で用いた「X10」の模型 (Fig4)は寸胴であり,樽型形状になっ ていない. 矢の仕様を Tablel に示した. 実物の 1.5 倍の X10の 模型を用いる. 磁力支持するために, 矢の内部に Nd 磁石を扱人 した.

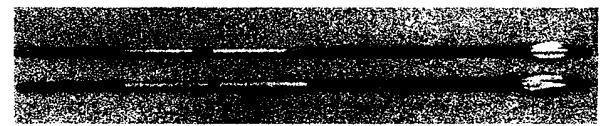

Fig. 3 アーチェリー久 $(1:$ X10, ト: A/C/E $)$

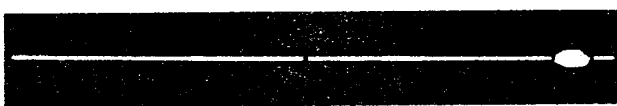

Fig. 4 X10 の模仵!

Table. 1 欠:0任栐

\begin{tabular}{|c|c|c|c|}
\hline シャフト & 个: $L_{\mathbf{k}}[\mathrm{m}]$ & 证徍 (壮) $[\mathrm{m}]$ & アスペクト比 \\
\hline $\mathrm{X} 10$ & $6.26 \times 10^{-1}$ & $4.82 \times 10^{-3}$ & $1.26 \times 10^{2}$ \\
\hline X10(惯型) & 1.00 & $7.98 \times 10^{-3}$ & $1.26 \times 10^{2}$ \\
\hline $\mathrm{A} / \mathrm{C} / \mathrm{E}$ & $6.26 \times 10^{-1}$ & $5.24 \times 10^{-3}$ & $1.16 \times 10^{2}$ \\
\hline
\end{tabular}

3.2 .1 鏃

実験で使用する鏃 2 種類 (椎型, 流線形) を Fig5, 6 に示す. 実 際の競技で使用する $\mathrm{X} 10$ と $\mathrm{A} / \mathrm{C} / \mathrm{E}$ の鏃形状はわずかに異なる.

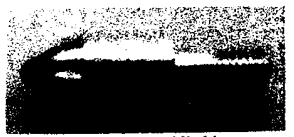

Fig. 5 椎㓫

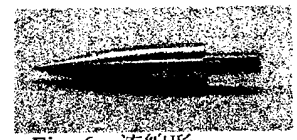

Fig. 6 流線扩

\begin{tabular}{|c|c|c|c|}
\hline 大の程类! & 鏃形状 & 个1: $1 \mathrm{~m}]$ & 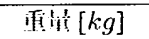 \\
\hline 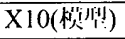 & 惟䓄! & $1.91 \times 10^{2}$ & $1.49 \times 10^{-3}$ \\
\hline $\mathrm{X} 10$ (模型 & 流線振 & $2.18 \times 10^{-2}$ & $1.36 \times 10^{-3}$ \\
\hline $\mathrm{A} / \mathrm{C} / \mathrm{E}$ & 椎型 & $1.07 \times 10^{-2}$ & $2.01 \times 10^{-3}$ \\
\hline$\overline{\mathrm{A} / \mathrm{C} / \mathrm{E}}$ & 流線珠 & $1.90 \times 10^{-2}$ & $2.49 \times 10^{-3}$ \\
\hline
\end{tabular}

3.2 .2 矢羽

本研究では, アーチェリ一競技において広く使用されている, SPIN-WING-VANE(Range-O-Matic Archery Company 社 : Fig7 下)の矢羽を川小いた. X10の模型にはこの矢羽の模型を川いた (Fig7 上). 各矢羽の仕様を Table3 に示す

3.3 飛翔実験

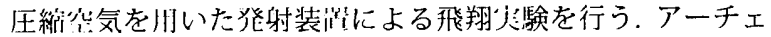
リー矢を焱射し，问速ビデオカメラを 2 台川いて掓影し，そ0映 像から速度減衰率 $\mathrm{D}$ を求め,(4) 式によって抗力係数 $C_{D}$ を算出

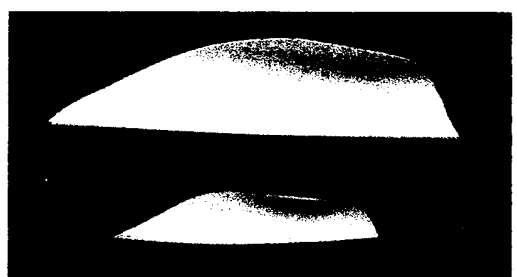

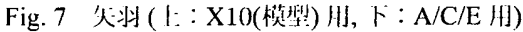

\begin{tabular}{|c|c|c|}
\hline 分の雬数门 & A 1. & ritece \\
\hline $\mathrm{X} 10($ 模等) & $6.59 \times 10^{-2}$ & $0.14 \times 10^{-3}$ \\
\hline $\mathrm{A} / \mathrm{C} / \mathrm{E}$ & $4.45 \times 10^{-2}$ & $0.93 \times 10^{-3}$ \\
\hline
\end{tabular}

する. 算出方法の詳細は「ながれ 2010」(2)を参照されたい.この 飛翔実験は, 国立スポーツ科学センター (JISS) の屋内競技場で 测定を行った。

\section{4. 実験結果}

4.1 回転数-速度の関係

䖝洞実験抢よび飛翔実騃における回転数と速度の関係をそれ ぞれ Fig8,9 に示す。

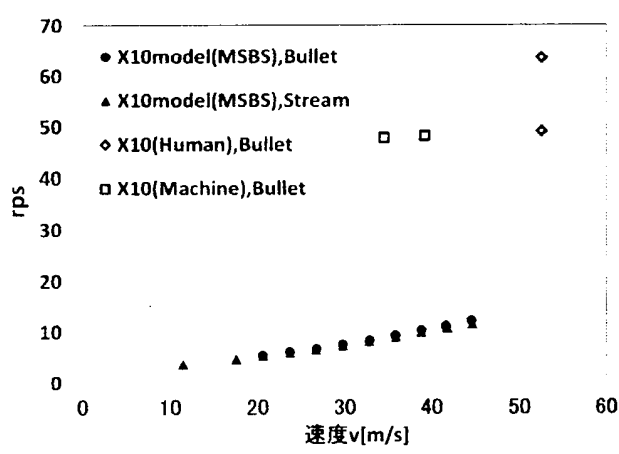

Fig. 8 川电公数-速洨 $(\mathrm{X} 10)$

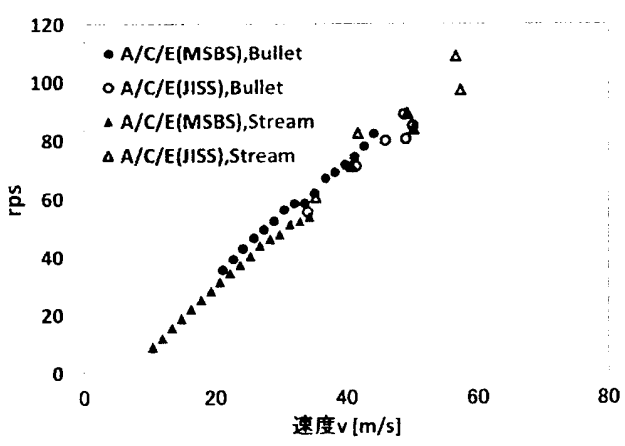

Fig. 9 回课擞-速度 $(\mathrm{A} / \mathrm{C} / \mathrm{E})$

Fig8, 9 より, 回転数と速度は比例関係であること, 回転数は先 端形状の違いに依存しないことが分かる.X10を用いた場合, 風 洞実験と飛翔実験を比べると, 風洞実騃では矢の回転数が極端に 低い結果となった. 風洞実験では, 矢の内部に挿入した磁石の軸 対称性が览く, 矢が回転した时に矢の们転を妨げる向きにトルク が墈いたことで, 回転数が低くなったと考えられる.あるいは矢 羽形状の阙题が考えられる. 今沁実験で川小いたアーチェリーの矢 羽はカール形状という被雑な形状をしているため, 模紫用の矢羽 ではその形状を惊现しきれなかった可能性がある.A/C/E を用

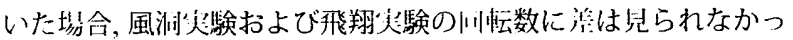
た.よって，風洞実験では矢の飛翔状態を再現できたと言える. 


\section{2 矢の絴 3 分力特性}

MSBS を用いた風洞実験では, 矢の迎角 $\theta$ を気流に対して -3 - $\leq \theta \leq 3^{\circ}$ の間で変えて, 縦 3 分力 (抗力係数 $C_{D}$, 揚力係数 $C_{L}$, 縦摇れモーメント係数 $C_{m}$ ) の測定を行った. Fig10〜12 に 測定結果を示し, $R e$ 数領域が近い值において, $\mathrm{X} 10$ と $\mathrm{A} / \mathrm{C} / \mathrm{E}$ の 比較を行った. また, Fig10〜 12 は, X10 および A/C/E の回転状 態のデータである.

Fig10 で X10 と A/C/E の抗力係数 $C_{D}$ を比較すると, Fig 10 から迎角への依存性に大きな違いはない. 両者とも矢の迎角が $\pm 0.5^{\circ}$ になると, 境界曆が層流から乱流に遷移する詣向が見ら れた.

次に Fig11より，揚力は迎角と比例関係であることがわかる. また, アスペクト比の違いによる揚力係数 $C_{L}$ への影響はほとん ど見られなかった. 揚力は主として矢羽の影響によるものだと考 えられる。

縦摇れモーメント係数 $C_{m}$ は迎角と比例関係であり,これは矢 の姿勢を示している. 両者とも矢に迎角をつけた場合, 矢の姿勢 を気流に対して平行にもどす方向にトルクが働いている. 両者を 比較すると, X10 の方が迎角に対する傾きは小さいことが分か る.このことから,アスペクト比の小さい $\mathrm{A} / \mathrm{C} / \mathrm{E}$ のほうが姿勢 安定度は大きいと言える。

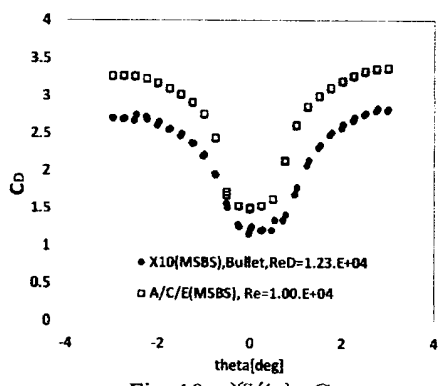

Fig. 10 迎栣と $C_{D}$

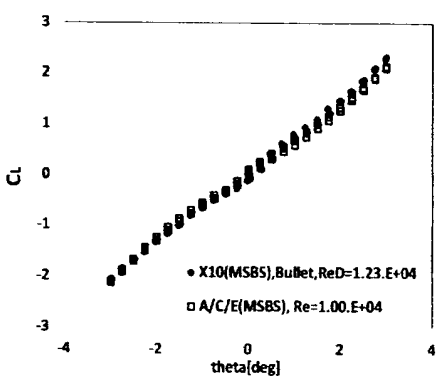

Fig. 11 迎角と $C_{L}$

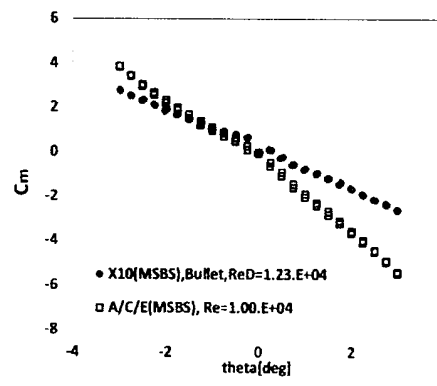

Fig. 12 迎任と $C_{m}$

\section{$4.3 C_{D}$ の $R e$ 数依存性}

\subsubsection{X10を用いた実験結果}

$X 10$ を用いた風洞実験における, 迎角 $0^{\circ}$ の $C_{D}$ と $R e$ 数依 存性执び飛翔実験の結果を Fig13 に示す.

\section{1. 風洞実験結果}

$\mathrm{X} 10$ の矢羽なしの状態でのデータを見ると, 椎型鐘, 流 線形銠ともに $R e \approx 1.8 \times 10^{4}$ まではほぼ同じ值となり， $R e$ 数の增加に伴い抗力係数 $C_{D}$ が低減している. また, 円柱の層流状態における抗力係数の理論値とほぼ一致し ていることから, 境界層の状態は層流である.しかし, 流線 形の鏣では $R e \approx 2.0 \times 10^{4}$ において $C_{D}$ 値が大きく変化 しているため, 境界畨が乱流遷移したと考えられる. 流線 形鏃が椎型鉦より先に遷移してしまったのは, 錇表面の粗

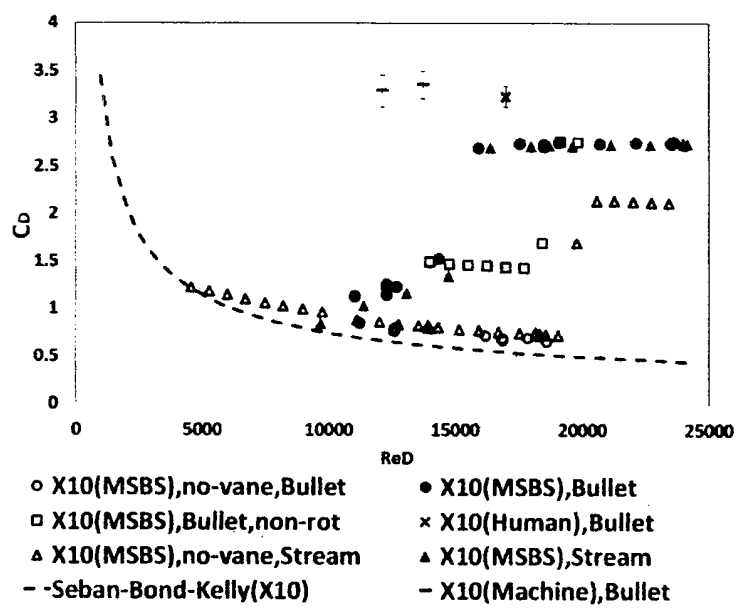

Fig. $13 C_{D}$ の $R e$ 数依存性 $(\mathrm{X} 10)$

度の影響の可能性がある.

矢羽が有り, 矢が回転しているデータでは, 矢羽無しの 状態の時と同様に, 椎型と流線形の鏃でほぼ同じ值をと り $R e \approx 1.5 \times 10^{4}$ で $C_{D}$ に大きな変化が見られる.この $R e$ 数で, 境界層が乱流に遷移したと考えられる. 矢羽無 しの時よりも, $R e$ 数が約 25 パーセント低いところで遷移 している.また, 層流および乱流状態での矢羽なしの時の 测定結果と比較すると, $C_{D}$ は 0.5 ほど增加している. 矢 羽有りでは, $1.0 \times 10^{4} \leq R e \leq 1.5 \times 10^{4}$ に扔いて $C_{D}$ が 徐々に增加し, $R e \approx 1.5 \times 10^{4}$ に㧊いて $C_{D}$ に大きな変 化が兒られた. 知が可転してない場合, $R e \approx 1.8 \times 10^{4}$ で $C_{D}$ に大きな変化が見られ，回転してる時よりも高い $R e$ 数まで境界層は層流状態であった。これは矢が回転しない ことによって,境界層の遷移する位置が変化したと考えら れる.

\section{2. 飛翔実験との比較}

$\mathrm{X} 10$ の矢における飛翔実験との比較を行う. $R e=1.2$ $\sim 1.3 \times 10^{4}$ での $C_{D}$ は, 飛翔実験の方が風洞実験より 2.0 程大きい. これは発射実験において, 矢の姿勢制御が不十 分であり, 矢に迎角がついてしまったと考えられる.. 矢が たわみ振動する実際の射手による矢の $C_{D}$ は, 風洞実験で の測定值より 0.5 大きい.これはたわみ振動の影響により 矢の姿勢が不安定になったためだと考えられる.

\section{4.3.2 アスペクト比の違う矢の比較}

$\mathrm{A} / \mathrm{C} / \mathrm{E}$ に対しても阔㥞の突験を行い X10 と比較を行った。 Fig14 には矢羽が無い時, Fig 15 には $\mathrm{A} / \mathrm{C} / \mathrm{E}$ 矢に矢羽がついてい る時の $C_{D}$ の $R e$ 数依保性を示した. 円柱の層流状態におる计る 抗力係数の理論佔において, $\mathrm{X} 10$ と $\mathrm{A} / \mathrm{C} / \mathrm{E}$ を比較すると, $C_{D}$ は $\mathrm{X} 10$ の方が大きい. しかし, 矢羽無しの状態で $1.1 \times 10^{4}<R e<$ $1.3 \times 10^{4}$ の $R e$ 数領域を比較すると, $C_{D}$ に差は見られない.こ れは, $\mathrm{A} / \mathrm{C} / \mathrm{E}$ (樽型形状) の平均断面積を抗力の無次元化に用いた ためであろう. $\mathrm{A} / \mathrm{C} / \mathrm{E}$ 矢の矢羽有りの状態で, 測定した $R e$ 数領 域 $\left(0.3 \times 10^{4}<R e<1.5 \times 10^{4}\right)$ では, 鏃形状に問わず境界層は 層流であった 


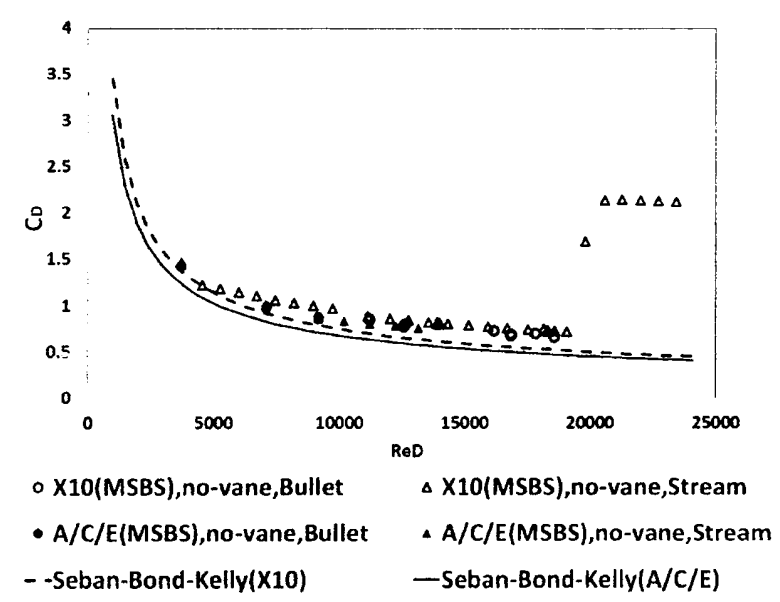

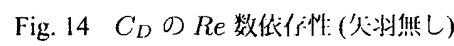

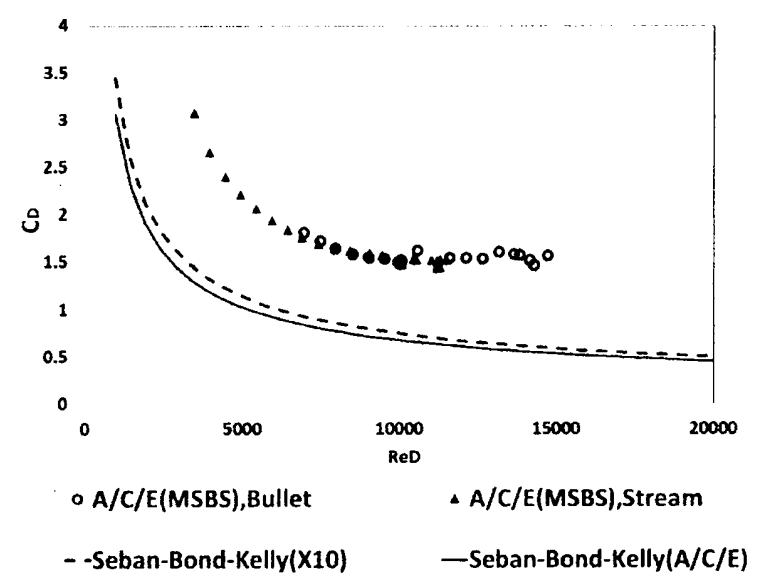

Fig. $15 C_{D}$ の $\operatorname{Re}$ 数低保吽 $(\mathrm{A} / \mathrm{C} / \mathrm{E})$

\section{5. 結言}

本研究では, アーチェリー矢である X10 矢の模型に対して, JAXA の MSBS 風洞実験を行った. また, アスペクト比が違う $\mathrm{A} / \mathrm{C} / \mathrm{E}$ 矢に対しても同様の実験を行い, 両者を比較した.

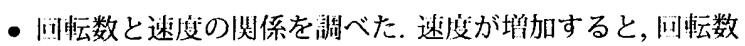
も比例して增加することが確認できた. $\mathrm{A} / \mathrm{C} / \mathrm{E}$ の矢を䏳い た風洞実験では実際の矢の飛翔状態を再現することがで きた. しかし, X10の矢を用いた風洞実験では, 矢の回転 数が飛翔実験と比べて極端に違うことから, 実際の飛翔を 再現するために今後検討する必要がある.

-アスペクト比の違う矢の縦 3 分力の比較を行った. アスペ クト比の違いは, 抗力と縦摇れモーメントに影響を及ぼす が,揚力には影響を及ぼさないことが分かった.

- $\mathrm{X} 10$ (模型) における抗力係数 $C_{D}$ の $R e$ 数依存性を測定 した. 矢羽無しの場合, 椎型鉃は乱流遷移せず,流線形鏃で は乱流遷移が見られた. 矢羽有りの場合, 先端形状の違い によらず刷流から乱流に簒移し, 矢が国転している时は矢 羽無しの時よりRe 数が 25 パーセント低いところで造移 した. 矢が回枟していない时は Re 数が 10 パーセント低

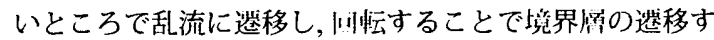
る位滥が変わった。

- アスペクト比の造う矢についての抗力係数 $C_{D}$ O Re 数 依存性の比較した. 円柱の層流状態における抗力係数の理
論値では,アスペクト比の違いは見られるが, 風洞実験の $R e$ 数領域では大きな違いが見られなかった.

\section{参考文献}

(1) Sawada,H.:Experimental Study of Aerodynamic Performance of Arrows with JAXA's $60 \mathrm{~cm}$ Magnetic Suspension and Balance System ,Theoretical and Applied Mechanics Japan, Vol.56, 2007, pp.237-242

（2）鈴木一史：矢の突力特性－境界储透移に対する先端形状の

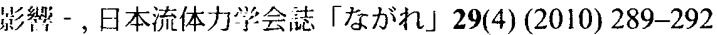

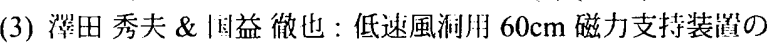

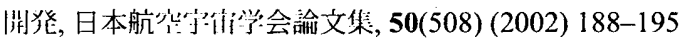

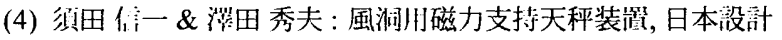
工学会誌, 41(5) (2006) 235-241 